DOI 10.15290/cnisk.2021.01.10.10

\author{
MAŁGORZATA DAJNOWICZ \\ https://orcid.org/0000-0001-6124-9983 \\ Uniwersytet w Białymstoku \\ URSZULA SOKOŁOWSKA \\ https://orcid.org/0000-0003-2449-4124 \\ Uniwersytet Medyczny w Białymstoku
}

\title{
Sama, ale czy samotna? - obraz niezamężnych kobiet u schyłku Polskiej Rzeczypospolitej Ludowej w świetle „Kobiety i Życia”
}

\begin{abstract}
Streszczenie
Na łamach prasy kobiecej wydawanej u schyłku Polskiej Rzeczypospolitej Ludowej coraz częściej pojawiały się wizerunki kobiet niezamężnych. Pomimo że materiały prasowe nadal w znacznym stopniu przedstawiały stereotypowe postrzeganie kobiet żyjacych w pojedynkę, zauważalne były istotne zmiany w kwestii prezentowania wizerunku oraz pozycji kobiet niezamężnych. Szczególnie dostrzegalne było to na łamach „Kobiety i Życia”, gdzie coraz więcej tekstów ukazywało samotność jako świadomy wybór Polek, które decydowały się na samodzielność nie z przymusu czy konieczności.
\end{abstract}

\footnotetext{
Publikacja przygotowana/finansowana w ramach programu Ministra Nauki i Szkolnictwa Wyższego pod nazwa DIALOG w latach 2019-2021. Jest wynikiem udziału w projekcie badawczym pt. „Ośrodek badań historii kobiet”, nr 0016/DLG/2019/10.
} 
W artykule zaprezentowano opinie kobiet na temat życia w pojedynkę, przyczyny, dla których podjęły decyzję o wyborze właśnie takiej drogi życiowej, oraz sposób postrzegania kobiet niezamężnych przez społeczeństwo polskie u schyłku Polskiej Rzeczypospolitej Ludowej. Analiza została oparta na publikacjach ukazujących się w „Kobiecie i Życiu”2. Autorki artykułu wyniki swoich badań odniosły także do materiałów prasowych publikowanych w innych czasopismach kobiecych okresu Polskiej Rzeczypospolitej Ludowej - „Przyjaciółki” oraz „Zwierciadła”.

Słowa kluczowe: prasa kobieca, „Kobieta i Życie”, Polska Rzeczpospolita Ludowa, kobieta niezamężna, kobieta rozwiedziona, życie w pojedynkę

\title{
ALONE, DOES IT MEAN LONELY? - THE IMAGE OF UNMARRIED WOMEN AT THE END OF THE POLISH PEOPLE'S REPUBLIC IN THE LIGHT OF "KOBIETA I ŻYCIE"
}

\begin{abstract}
In the women's press, published at the end of the Polish People's Republic, images of unmarried women were increasingly appearing. Despite the fact that press releases still largely portrayed the stereotypical perception of single women, significant changes were seen in the presen-

2 „Kobieta i Życie” była pierwszym odrębnym czasopismem kobiecym powstałym po drugiej wojnie światowej. Premierowy numer pisma ukazał się w 1946 r. pod tytułem „Moda i Życie Praktyczne". W kolejnych latach nastapiło połączenie miesięcznika z periodykiem „Kobieta”, co skutkowało utworzeniem „Kobiety i Życia Praktycznego”, od 1953 r. ukazującego się jako „Kobieta i Życie”. Czasopismo ukazywało się nieprzerwanie do 1981 r., co ściśle zwiazane było $z$ ówczesnymi wydarzeniami politycznymi, a zwłaszcza wprowadzeniem stanu wojennego, który na kilka miesięcy zawiesił wydawanie prasy codziennej. Nowy etap „Kobiety i Życia” rozpoczął się reaktywowaniem pisma w kwietniu $1982 \mathrm{r}$. W latach 80. XX w. wokół redakcji periodyku utworzył się swoisty ruch feministyczny, a łamy czasopisma zostały wypełnione artykułami dotyczącymi dyskryminacji kobiet w różnych dziedzinach życia. Zob m.in.: Małgorzata Dajnowicz, „Kobiety w polityce w wypowiedziach prasowych Krystyny Kaszuby na łamach "Kobiety i Życia" (1985-1990)", w: Ewa Maj, Ewelina Podgajna, Anna Szwed-Walczak, Łukasz Jędrzejski (red.), Komunikowanie polityczne, (Lublin: Wydawnictwo UMCS, 2017), 200; eadem, „Wzorce aktywności publicznej kobiet w początkach transformacji ustrojowej w Polsce w świetle "Kobiety i Życia" i "Urody" (1989-1995)", w: Teresa Kulak, Małgorzata Dajnowicz (red.), Drogi kobiet do polityki (na przestrzeni XVIII-XXI wieku), (Wrocław: Wydawnictwo Chromcom, 2016), 420; Urszula Ćwik, „Wybory parlamentarne i wybory do rad narodowych w Polskiej Rzeczypospolitej Ludowej na łamach "Kobiety i Życia" (do 1989 roku)", w: Małgorzata Dajnowicz, Adam Miodowski, Polityka i politycy w prasie XX i XXI wieku, (Białystok: Wydawnictwo Humanica, 2016), 329-330; eadem, „Podstawowe założenia Społeczno-Obywatelskiej Ligi Kobiet w świetle "Mody i Życia Praktycznego“ (1946-1951)”, w: Małgorzata Dajnowicz, Adam Miodowski (red.), Polityka i politycy w prasie XX i XXI wieku. Prasa organizacji politycznych, (Białystok: Wydawnictwo Humanica, 2017), 51-52.
\end{abstract}


tation of the image and position of unmarried women. It was particularly noticeable in the pages of Kobieta $i$ Życie where more and more texts showed loneliness as a conscious choice of Polish women who decided to become independent, not from coercion or necessity.

The article presents women's opinions on the subject of single life, the reasons for which the decision was made to choose such a way of life and the way Polish society perceive unmarried women at the end of the Polish People's Republic. The analysis was based on publications appearing in Kobieta $i$ Życie. The authors of the article, results of their research also referred to press materials published in other women's magazines of the Polish People's Republic - Przyjaciótka and Zwierciadło.

Keywords: women's press, Kobieta i Życie, Polish People's Republic, unmarried woman, divorced woman, single life

\section{Uwagi wstępne}

Na łamach prasy kobiecej ukazujacej się w drugiej połowie lat 80. XX w. coraz częściej pojawiał się wizerunek kobiet niezamężnych. Publikowane teksty, choć nie były wolne od wciąż aktualnych stereotypów, przedstawiały zagadnienia dotyczace kobiet, które w wyniku własnych wyborów i innych okoliczności życiowych pozostawały poza związkiem małżeńskim. Omawiana problematyka występowała szczególnie często w listach do redakcji. Po analizie materiałów napływających od czytelniczek można było zauważyć zachodzace zmiany społeczne, polegajace na świadomej rezygnacji kobiet $z$ małżeństwa, co stwarzało możliwości do swobodnego dysponowania wolnym czasem, korzystania $z$ rozrywek oraz realizacji własnych aspiracji zawodowych.

Zmiany dokonujące się we współczesnym społeczeństwie wpłynęły na kształt przemian zachodzacych w obrębie małżeństwa i rodziny. $Z$ wielu badań naukowych, ale również $z$ ogólnej obserwacji życia społecznego wynika, że coraz częściej rodzina przestaje funkcjonować jedynie w postaci formalnego związku, ale także w oparciu o związki nieformalne. Upowszechniają się również alternatywne wobec rodziny formy życia, takie jak chociażby życie w pojedynkę, które nie stanowi całkowicie nowego zjawiska, gdyż występowało w każdym społeczeństwie niezależnie od epoki i typu kultury ${ }^{3}$.

3 Julita Czarnecka, „Polski singiel: obraz w mediach a autowizerunek”, w: Ewa Malinowska (red.), Stereotypy a rzeczywistość na przykładzie wybranych kategorii społecznych, (Łódź: Oficy- 
Na przełomie XIX i XX w. forma życia w pojedynkę była powszechnie akceptowana w odniesieniu do kobiet, pod warunkiem że zdecydowały się poświęcić swoje życie innym. $Z$ tego powodu pracowały jako guwernantki, służące, damy do towarzystwa czy nauczycielki. Kolejne wojny światowe zaburzyły demograficzne proporcje. Wielu mężczyzn zginęło na froncie, co wpłynęło na duży odsetek wdów wśród ówczesnych kobiet. $Z$ kolei w latach 60. XX w. coraz silniej oddziaływająca kultura masowa, szczególnie obecna w Stanach Zjednoczonych, zaczęła mieć kluczowy wpływ na kształtowanie się określonego stylu życia. Wówczas zaszło wiele społecznych przemian, które przyczynily się do rozpadu tradycyjnej formy rodziny i dały początek alternatywnym formom ${ }^{4}$.

Niezamężne kobiety, do niedawna określane zgodnie przez wszystkich mianem „starych panien”, zapisały się gdzieś na marginesie dziejów jako kobiety niemajętne, nieatrakcyjne, często zgorzkniałe i wzbudzające litość. Ogólnie rzecz ujmując, jako istoty godne pożałowania, dla których brak męża u boku oznaczał niski status społeczny, a nawet wykluczenie. Źródła archetypu „starej panny" należy upatrywać głównie w literaturze, która dała początek takiemu postrzeganiu kobiet samotnych. Wystarczy wspomnieć Martę Korczyńską z Nad Niemnem - uboga krewna, „... sczerniałe, spracowane, poczciwe kobiecisko zanoszące się kaszlem"5, pozostające na łasce rodziny. Dawniej określenie „stara panna” dotyczyło kobiet, których życie postrzegano jako życiowa porażkę, wynik bezradności, brzydoty czy złego charakteru. Mocno zakorzeniony w społeczeństwie polskim stereotyp samotnej kobiety jako biernej, pozostawionej samej sobie został wyparty przez wizerunek kobiety, dla której samotność to nie tylko konieczność, ale również świadomy wybór. Materiały uzasadniające, że życie w pojedynkę to także zamierzony sposób funkcjonowania $\mathrm{w}$ społeczeństwie, zaczynały coraz silniej pojawiać się na łamach prasy kobiecej u schyłku PRL. I choć zamieszczane publikacje nie były całkowicie pozbawione utrwalonych stereotypów, to wyraźnie można było zauważyć w nich zachodzące zmiany w zakresie prezentowanych ról społecznych.

na Wydawnicza Tercja, 2008), 110-113; Krystyna Slany, Alternatywne formy życia małżeńsko-rodzinnego w ponowoczesnym świecie, (Kraków: Zakład Wydawniczy Nomos, 2002), 13-22.

4 Ibidem.

5 Kazimiera Szczuka, „Sama nie samotna”, Serwis Informacyjny Tygodnika Polityka, [online] [dostęp: 30.01.2017]. Dostępny w World Wide Web: <http://www.polityka.pl/tygodnikpolityka/kultura/254106,1,sama-nie-samotna.read>. 
Każdy przełom polityczny wywierał kluczowy wpływ na kształt czasopiśmiennictwa, również tego adresowanego do kobiet. Zakończenie drugiej wojny światowej rozpoczęło nowy okres dziejów prasy kobiecej. W PRL ukazało się wiele nowych tytułów, a ich typologia, rodzaje oraz odbiór czytelniczy bezustannie się zmieniały. Jednak niezmiennie wśród najpopularniejszych czasopism, cieszących się największym zainteresowaniem czytelniczek, pozostawały „Kobieta i Życie”, „Przyjaciółka” oraz „Zwierciadło”.

Problematyka poruszana na łamach każdego $z$ tych czasopism skupiała się wokół podobnych zagadnień, typowych dla prasy kobiecej. Wśród nich wyróżnić można rodzinę $\mathrm{w}$ aspekcie emocjonalnym, czyli miłość, relacje między poszczególnymi jej członkami, jak również sprawy bytowe w ujęciu ekonomicznym, związane $z$ funkcjonowaniem gospodarstwa domowego. Kolejnym blokiem tematycznym była aktualna pozycja kobiet, ich działalność publiczna, walka o równe $z$ mężczyznami prawo do podmiotowości, pracy zawodowej, jednakowych szans na osiagnięcie sukcesów czy możliwość sprawowania władzy politycznej. Jednak liczba materiałów z poszczególnych bloków tematycznych, jaka była publikowana w trzech wyżej wymienionych periodykach, znaczaco się różniła, a zależało to przede wszystkim od grona odbiorców, do których kierowane były czasopisma ${ }^{6}$.

\section{Wizerunek niezamężnych kobiet prezentowany na lamach „Kobiety i Życia”}

Stereotyp rozumiany jako szablon, tradycyjny, zazwyczaj irracjonalny, zabarwiony wartościująco obraz rzeczy, osób i instytu$\mathrm{cji}^{7}$, używany jest $\mathrm{w}$ wielu dyscyplinach naukowych, mediach oraz języku potocznym. Współcześnie definiowany jest również jako zbytnio uproszczone i sztywne pojęcie o zbiorowiskach ludzi, w których wszystkim przypisywana jest tzw. charakterystyka grupowa.

\footnotetext{
6 Trzy najbardziej popularne periodyki kobiece ukazujące się w Polsce Ludowej, czyli „Przyjaciółka”, „Kobieta i Życie” oraz „Zwierciadło”, adresowane były do zupełnie odmiennych grup kobiet, na co zwracano uwage w wielu opracowaniach, jak również oficjalnych dokumentach PZPR. Zob. AAN, PZPR KC Wydział Prasy i Wydawnictw, sygn. 237/XIX - 208, Uwagi o prasie kobiecej. „Kobieta i Życie”, „Przyjaciółka”, „Zwierciadło”, styczeń-maj 1958 r., k. 1.

7 Władysław Kopaliński, Słownik wyrazów obcych i zwrotów obcojęzycznych z almanachem, (Warszawa: Oficyna Wydawnicza Rytm, 2014), 472-473; Słownik języka polskiego PWN, hasło: stereotyp, [online] [dostęp: 4.05.2017]. Dostępny w World Wide Web: <http:// sjp.pwn.pl/sjp/;2576254>.
} 
Pomijana jest natomiast indywidualna niepowtarzalność jednostek, a różnorodność i złożoność redukowane są do kilku kategorii ${ }^{8}$. Podobnie jest w wypadku stereotypu „starej panny”, na który składaja się uproszczone sądy i koncepcje zachowań niezamężnych kobiet.

Na podstawie analizy materiałów publikowanych w wysokonakładowych periodykach kobiecych stwierdzić można, że w drugiej połowie lat 80 . XX w. niestety nadal był obecny stereotyp „starej panny", szczególnie mocno akcentowany na łamach niektórych czasopism. Jednak zaznaczyć należy, że w wypadku „Kobiety i Życia" liczba materiałów o negatywnym postrzeganiu niezamężnych kobiet stanowiła znacząca mniejszość w porównaniu z tymi, w których podkreślano zachodzace zmiany nastrojów społecznych w ich odbiorze $^{9}$. Czytelniczki periodyku same zwracały uwagę na problematykę samotności i niesłusznego utrwalania stereotypu samotnej kobiety w społeczeństwie. Jedna $z$ nich apelowała:

Czy panie redaktorki wiedza, ile wspaniałych dziewczyn, ile błyskotliwych karier złamała ta podstępna, bo przecież niewidoczna choroba. Choroba niszczaca, osłabiająca człowieka, pomniejszajaca jego życiowe szanse. Zróbcie coś, na Boga! Powiedzcie przynajmniej, że samotność to nie kara boska, nie piętno na całe życie. $Z$ perspektywy małego miasteczka, w którym żyję, tak to właśnie wygląa ${ }^{10}$.

W analizowanych wydaniach „Kobiety i Życia” sygnalizowano istnienie utrwalonych stereotypów płci, zgodnie $z$ którymi podstawowa rola kobiety ograniczała się do bycia towarzyszka życia mężczyzny i matką. Jednak teksty uwidaczniające negatywny stosunek do kobiet niezamężnych praktycznie nie występowały. Jedyny wyjattek stanowiła wypowiedź „Kelnera z Warszawy”, który stwierdził, że „... gdy kobieta przychodzi na dansing bez mężczyzny,

\footnotetext{
8 Eugenia Mandal, Podmiotowe i interpersonalne konsekwencje stereotypów zwiazanych z płcia, (Katowice: Wydawnictwo Uniwersytetu Ślasskiego, 2000), 13.

9 Zdecydowanie odmiennie było w wypadku „Przyjaciółki”, na której łamach wciąż przeważało stereotypowe postrzeganie samotnych kobiet. W periodyku publikowano materiały ukazujące nadal istniejący w polskim społeczeństwie lat 80. tradycyjny podział ról społecznych ze względu na płeć i konieczność „wyjścia za mąż. Pisano: „Mówi się, że kobieta, choćby nie wiem jakie miała plany związane ze zdobywaniem wiedzy i praca zawodowa, i tak nie uniknie swojego przeznaczenia: małżeństwa i macierzyństwa. Najradośniej brzmi marsz Mendelssohna młodym uszom i zwykle radzi się właśnie dwudziestoparolatkom zakładanie rodzin”. Zob. „Z różnych szpalt. Kiedy wyjść za mąż?”, Przyjaciółka, nr 10, 1987, 11.

10 „Piętno. Wokół samotności”, Kobieta i Życie, nr 18, 1988, 10.
} 
uważam, że szuka okazji. Jej samotność to propozycja. Nie mam zbyt dobrego o niej zdania i nigdy nie traktowałbym jej poważnie"11. Aczkolwiek należy zwrócić uwagę, że cytowana wypowiedź została umieszczona wśród innych zdecydowanie bardziej obszernych tekstów nadesłanych od czytelniczek, które stanowiły doskonałe potwierdzenie zmian zachodzacych $\mathrm{w}$ postrzeganiu pozycji niezamężnych Polek.

W tekstach publikowanych na łamach „Kobiety i Życia” wielokrotnie podkreślano, że pojęcie „stara panna” zaczynało wychodzić z użycia. Pisano, że w analizowanym okresie samotność nie stanowiła hańby czy powodu do wstydu. W sposób ironiczny mówiono o zaleceniach w stosunku do sposobu zachowania niezamężnych kobiet, jakie były zamieszczane w latach 20 . XX w. w podręcznikach dobrych manier: „... rozwódka powinna schronić się w zaciszu domowym, najlepiej u rodziców byłego męża. Po paru latach będzie mogła się pokazać już w teatrze, ale pod opieką starszej krewnej"12. Jednocześnie w „Kobiecie i Życiu” pisano, że „... mianem "starej panny" nie ma już kogo nazywać"13, gdyż nastała zupełnie inna rzeczywistość, w której kobiety decyduja się na samotność z wyboru, „.. a sama przyczyna samodzielności nie ma większego znaczenia. Panna, rozwódka czy wdowa - obojętne. Zapanowała równość"14.

Redakcja czasopisma starała się walczyć ze stereotypem „starej panny” przy użyciu materiałów o charakterze prześmiewczym, stosując ironię oraz sarkazm. W jednym $z$ felietonów opublikowanych na łamach „Kobiety i Życia” pisano:

Stara pannę ma się u nas za nic. Nie przysparza państwu nowych obywateli, telewizja nie może się do niej zwrócić w krytycznych momentach $z$ pytaniem, jakie jest stanowisko żon i matek, nie została żoną rolnika, ani żadnego innego mężczyzny, który dzięki jej poświęceniu dla domu mógł poświęcić się dla kariery. Jednym słowem - postać bez sensu. Taki schematyczny punkt widzenia powoduje, że stare panny spycha się na dalszy plan przy rozdziale wszystkich dóbr reglamentowanych i nikt jej imieniem nie nazywa najmniejszej nawet budki z gazetami, co dopiero mówić o Szpitalu-Pomniku ${ }^{15}$.

\footnotetext{
„Iść czy nie iść. Wokół samotności”, Kobieta i Życie, nr 33, 1988, 11.

„Inny gatunek kobiety?”, Kobieta i Życie, nr 9, 1984, 2.

Ibidem.

Ibidem.

„Sens społeczny starej panny”, Kobieta $i$ Życie, nr 34, 1984, 15.
} 
W dalszej części tekstu jego autorka żartobliwie zwracała uwage na fakt, że rola samotnych kobiet, którym przypisuje się cechy charakterystyczne utrwalonego wzorca „starej panny”, była niezwykle doniosła, lecz niewymierna, niepoliczalna, której nie dało się wstawić do statystyk ${ }^{16}$. Przede wszystkim:

„stara panna” podnosi samopoczucie wdów i rozwódek. Wszystkim trzem żyje się na co dzień tak samo ciężko, a jeśli wdowa czy rozwódka mają dzieci, to nawet im ciężej, ale za to posiadają w szafie jakiś zapomniany krawat, w albumie jakieś stare zdjęcie, a taka stara panna nic, nawet porządnych wspomnień. Następną nieoceniona przysługa, jaka stara panna oddaje społeczeństwu, jest jej rola „zapchajdziury” i „lekarstwa na nudę”. - Wiesz - mówi mężatka Wiśniewska - mąż wyjeżdża w delegację, może byś wpadła? ${ }^{17}$

Publikacje zamieszczane w „Kobiecie i Życiu” pozwalały zbudować portret osobowy kobiet niezamężnych u schyłku PRL. Warto zacząc od analizy źródeł samotności przedstawianych Polek i odpowiedzi na pytanie, czy decyzja o samotności była wynikiem określonych okoliczności życiowych, czy dobrowolnym wyborem.

Wśród przyczyn, $z$ jakich kobiety wybierały samodzielne życie, wymieniano po prostu brak chęci na „wyjście za mąż" czy poczucia potrzeby funkcjonowania w jakimkolwiek zwiąku - formalnym czy nieformalnym:

Podobno jedna na dziesięć dziewczyn nie ma ochoty na małżeństwo. Ja widocznie jestem tą ,jedna”. Jestem atrakcyjna (niedawno skończyłam czterdziestkę), nadal czuję się młoda i wciaż robię wrażenie na mężczyznach, nawet na dwudziestokilkuletnich. Przez całe swoje życie nie umiałam, nie chciałam wiazać się na stałe. Zawsze miałam bardzo wysokie wymagania i mogłam dobrze wyjść za mąż ${ }^{18}$.

Takimi słowami jeden $z$ listów rozpoczynała jego autorka, jednocześnie dodając:

Podziwiam kobiety zajmujące się domem, dziećmi i mężem. Ja nie lubię gotowania, sprzątania, prania itd. To nie dla mnie! Jestem zbyt wygodna i cenię wolność. Wszystkie moje koleżanki wyszły za

\footnotetext{
Ibidem.

17 Ibidem.

18 „Jestem sama, ale nie samotna. Wokół samotności (2)”, Kobieta i Życie, nr 33, 1988, 11.
} 
mąż, mają dzieci, ale ja naprawdę niczego im nie zazdroszczę. Nie umiem tak żyć. Zawsze miałam interesujace znajomości, miałam i mam jeszcze powodzenie. Lubię swoja samotność, chociaż nie czuję się samotna, i właściwie nigdy nie byłam, i nie jestem samotna, chociaż jestem sama. Natomiast żal mi tych zabieganych, zapracowanych żon ${ }^{19}$.

Można zauważyć, że niezamężne kobiety mówiły wprost o tym, iż zdecydowały się na samodzielność np. ze względu na swoja wygodę, swobodne dysponowanie czasem wolnym oraz na szeroko rozumiana niezależność. Należy zwrócić uwagę na fakt, że jest to znaczaca zmiana postawy w stosunku do wcześniejszego okresu, w którym kobiety starały się stawiać na pierwszym miejscu dobro innych, przede wszystkim najbliższych - męża lub dzieci.

Jednym $z$ najczęściej wymienianych powodów samotności były jednak przykre doświadczenia $z$ przeszłości, których doznały kobiety:

Czemu one nie chca chcieć? Chyba $z$ nadmiaru wiedzy o życiu. Wszędzie pełno odstraszających przykładów. Najbardziej boją się męża alkoholika, który jednego dnia będzie potworem, a drugiego aniołem, a one nie wytrzymaja takiej upiornej huśtawki. Niektóre $z$ nich zdają sobie sprawę $z$ tego, że mężczyzna marzy o innym małżeństwie, a ona o innym. Jej potrzebne jest małżeństwo partnerskie, jemu nie. On czułby się najlepiej w układzie tradycyjnym, w którym maż jest szefem, a żona personelem ${ }^{20}$.

W innym liście jego autorka $z$ kolei pisała: „Jestem samotna czterdziestolatka, mieszkam w Warszawie, mam wykształcenie wyższe techniczne, jestem w dobrej sytuacji materialnej i mieszkaniowej ... Jestem rozczarowana kontaktami z mężczyznami i straciłam już nadzieję na założenie rodziny"21. Na podstawie przytoczonych fragmentów wypowiedzi należy stwierdzić, że samotność większości kobiet była wynikiem określonych okoliczności życiowych. Najczęściej wśród nich wyróżniano rozczarowanie wynikające $z$ niepowodzeń we wcześniejszych związkach, które niejednokrotnie w wypadku związków małżeńskich kończyły się rozwodami ${ }^{22}$.

\footnotetext{
Ibidem.

20 „Inny gatunek kobiety?”, 2.

21 „Jestem rozczarowana mężczyznami. Wokół samotności (3)”, Kobieta i Życie, nr 45, 1988, 10.

22 Warto zwrócić uwage, że problematyka rozwodów była podejmowana na łamach wszystkich czasopism kobiecych, jednak w zupełnie inny sposób. Na łamach „Kobiety i Życia” te-
} 
Nie czuję się samotna, bo jestem $z$ synem, którego sama wychowuję i który jest dla mnie ważną osobą w życiu. Lubimy się, cenimy i jesteśmy zaprzyjaźnieni. Wykonuje pracę, którą lubię, która zmusza mnie do zastanawiania się nad wieloma sprawami. Nie czuję się samotna, ponieważ mam kilku dobrych przyjaciół, wielu znajomych, także w miejscach odległych. Jestem wciaż młodą kobietą i mam świadomość, że mogę wybrać inny model życia. Myślę, że przeszedłszy przez wiele osobistych klęsk i rozczarowań (nie tylko), stałam się bardziej wrażliwa na innych, nauczyłam się wiele, rozwinęłam swoją osobowość, więcej żądam od siebie, a także, że zdobyłam pewne umiejętności ogólne, jak na przykład: żeby cieszyć się czasem teraźniejszym, danym dniem, że ode mnie zależy, jaki on będzie. Że trzeba dbać o przyjaźnie, o uczucia ludzi bliskich, trzeba je w jakimś sensie pielęgnować i cenić. Że właściwie każdy dzień wymaga swoistego męstwa, że jak się chce, można - nadać mu jeszcze dodatkowy sens ${ }^{23}$.

\section{Przytoczony fragment listu jednej z czytelniczek - samotnej matki $^{24}$ stanowi doskonałe potwierdzenie tego, że kobiety decy-}

mat poruszano w kontekście refleksji nad wpływem takiego wydarzenia na życie rozwódek ich samopoczucia, sposobów radzenia sobie z samotnościa, odbioru przez społeczeństwo itd. Idealne potwierdzenie stanowi jeden $z$ „Wywiadów na zamówienie” z psychologiem dr Anną Pohorecka, która w obszernym materiale próbowała wyjaśnić czytelniczkom, dlaczego problemy wynikające po zawarciu związku małżeńskiego niektórych przerastają. Jednocześnie przekonywała, iż nie warto za wszelką cenę próbować ratować małżeństwa - które szans na prawidłowe funkcjonowanie niestety już nie ma - np. ze względu na dobro dzieci. Zob. Alicja Bielicka, „Trudny układ”, Kobieta $i$ Życie, nr 32, 1988, 17. Z kolei np. w „Przyjaciółce” zwracano uwage wyłącznie na dobro dzieci pozostających w „niekompletnej” rodzinie oraz aspekt ekonomiczny, czyli udzielano wskazówek kobietom, jak maja zapewnić byt materialny swoim dzieciom, żeby te $z$ kolei nie odczuły braku ojca w kontekście spełniania podstawowych potrzeb. Redakcja „Przyjaciółki” nie podejmowała problematyki dotyczacej samopoczucia rozwiedzionych kobiet, natomiast skupiała się wyłącznie na dzieciach, co może stanowić potwierdzenie, że na łamach periodyku konsekwentnie lansowano rolę kobiety jako przede wszystkim matki, dopiero później jako tej, która dba o swoje potrzeby, zdrowie oraz komfort psychiczny. W jednym $z$ tekstów pisano: „A czym jest rozwód dla dzieci? Znana jest powszechnie teza, że bywa on często przyczyną psychicznych odchyleń, szczególnie wśród młodzieży. Zdarzające się próby dziecięcych samobójstw, duża liczba małoletnich przestępców pochodzaca $z$ rozbitych rodzin - stanowia niezbite tego dowody". Zob. Janina Ratyńska, „Rozwody i dzieci”, Przyjaciółka, nr 21, 1987, 3.

23 „Nie czuję się samotna. Wokół samotności”, Kobieta i Życie, nr 18, 1988, 11.

24 Problematyka dotyczaca matek samotnie wychowujacych dzieci znalazła odbicie na łamach „Zwierciadła”. W kilku kolejnych wydaniach periodyku z lat 80. XX w. prowadzono dyskusję na temat sytuacji samotnych matek. Wśród nadesłanych listów przeważały opinie o zbyt dużych udogodnieniach przyznanych ze strony państwa, np. pierwszeństwo dzieci samotnych matek w procesie rekrutacji do przedszkoli. Pojawiło się też kilka wypowiedzi o charakterze negatywnie oceniającym decyzje kobiet, które zdecydowały się rozstać z ojcami swojego potomstwa. Na łamach czasopisma opublikowano również list kobiety, która apelowała do czytelników: „Nie oceniajmy zbyt pochopnie tych kobiet, które decyduja się na samotne wychowywanie dzieci. Być może jest to rodzina okaleczona, ale ile jest rodzin for- 
dujące się na samodzielne życie były dojrzałe, a ich postępowanie nie było przypadkowe. W swoich wypowiedziach często podkreślały, że oparcie znajdowały w przyjaciołach, rodzinie oraz dzieciach. Zapewne początkowo nie było im łatwo pogodzić się z nową sytuacja i samotność traktowały jako przymus. Jednak wraz z upływem czasu zaczęły dostrzegać pozytywne strony swojego położenia i cieszyć się swobodnym życiem, w którym mogły bez wyrzutów sumienia realizować swoje pragnienia. Podobnie było w wypadku "Optymistki z Chorzowa”, która na łamach „Kobiety i Życia” dzieliła się swoja historią. Pisała, że wyszła za mąż młodo, a jej wybranek „... wydawał się porządnym człowiekiem, który nie pił a nawet nie palił. Wszystkie koleżanki zazdrościły mi tego szczęścia”25. Po kilku latach wspólnego życia mąż czytelniczki wyjechał za granicę, zostawiając ją $z$ małymi dziećmi ${ }^{26}$, lecz ona zamiast smutku i tęsknoty czuła radość i ulgę:

Niestety, przez tych pięć lat zdołałam wiele zrozumieć, również to, czym jest małżeństwo dla mojego męża. Żyłam w wiecznym strachu i napięciu. Nie, nie, mój mąż nie pił. On robił awantury na trzeźwo. Ubliżał mi i ranił $z$ byle powodu. Mój pan i władca pozbawił mnie radości życia i swobody. Nie mogłam mieć odmiennego niż on zdania. Kropla goryczy przelała się, gdy mnie uderzył... ${ }^{27}$

malnie pełnych, a okaleczonych jeszcze bardziej? Nawet wtedy, gdy nie ma alkoholu, awantur, a jest dwoje zimnych i obojętnych ludzi, którzy uważają, że będąc ze sobą poświęcają się dla swoich dzieci, a w gruncie rzeczy stwarzają im tylko nieznośna sytuację. Czasami jedna kobieta potrafi stworzyć swojemu dziecku znacznie lepszą atmosferę domową". Należy jednak wyraźnie zaznaczyć, że przytoczony fragment stanowił znaczna mniejszość w stosunku do wypowiedzi negatywnie postrzegajacych samotne matki. Zob. „Samotne, samodzielne czy wyzwolone?”, Zwierciadło, nr 50, 1985, 4.

25 „Nie rozpamiętywać minusów! Wokół samotności (3)”, Kobieta i Życie, nr 45, 1988, 10.

26 Wątek wyjazdu męża za granicę występował również w jednym $z$ materiałów opublikowanych na łamach „Zwierciadła”. Jego kontekst był jednak zupełnie inny niż ten, który ukazany został w „Kobiecie i Życiu”. W tekście o wymownym tytule „A kobieta wiernie czeka...” redakcja „Zwierciadła” opisywała historie kilku rodzin, w których mąż, czyli głowa rodziny, wyjechał za granicę w celach zarobkowych. Pisano o skutkach, jakie niesie podjęcie takiej decyzji - o tęsknocie i rozłące, o wychowywaniu dzieci i obarczeniu kobiet wszystkimi obowiązkami dotyczącymi domu i rodziny. W materiale można było odnaleźć współczucie względem samotnych kobiet pozostawionych w kraju, jednak puenta artykułu zmierzała ku temu, że obowiązkiem kobiety jest posłuszne i wierne czekanie na powrót ukochanego męża. Tym samym wydaje się, że redakcja czasopisma utrwalała tradycyjne i stereotypowe postrzeganie roli kobiety i mężczyzny w społeczeństwie. Zob. Katarzyna Stachowicz, „A kobieta wiernie czeka...", Zwierciadło, nr 1, 1983, 3.

27 „Nie rozpamiętywać minusów!...”, 10. 
Kobieta podkreślała, że nie czuła się sama, gdyż oparcie znalazła w rodzicach, siostrze oraz dzieciach. Ponadto od momentu rozstania odzyskała spokój i wiarę w siebie, mogła realizować się zawodowo, co przynosiło jej satysfakcję osobista i finansową oraz szacunek ludzi ${ }^{28}$. Swój list kończyła słowami: „Świat nie jest taki czarny, jak go niektórzy malują. Jest w nim wiele barw, trzeba ich tylko poszukać!"29.

Warto zaznaczyć, że to właśnie w latach 80. XX w. niezamężne Polki coraz częściej publicznie wyrażały swoje potrzeby. Silnie akcentowały konieczność zmian w tradycyjnym ujmowaniu ról społecznych kobiet i mężczyzn oraz podziału na sferę typowo kobieca i męską ${ }^{30}$. Ponadto przestały ulegać konwenansom i postępowaniu w taki sposób, by nie narazić się na negatywny odbiór ze strony społeczeństwa. Bardziej dbały o swój komfort psychiczny, życie w zgodzie ze swoimi przekonaniami, a nie podporzadkowywanie się schematom.

Wśród listów nadsyłanych do redakcji „Kobiety i Życia” można było odnaleźć również głosy kobiet zamężnych, które świadczyły o pozytywnym nastawieniu i akceptacji tych Polek, które zdecydowały się na życie w pojedynkę. Jedna $z$ nich - Zofia B. wyrażała opinię, że:

nie ma czego zazdrościć zamężnym. Ileż tam nieszczęścia, kiedy życie się nie układa, ile kłopotów, troski, zmartwień o tego męża, ile zmartwień o dzieci. Ciagły stres, bo dziecko chore, bo maż, bo wnuczka itd. A kiedy przyjdzie starość? Strach pomyśleć, że może ten bliski ukochany odejdzie na zawsze i zostanie wielka rana w sercu ${ }^{31}$.

\footnotetext{
28 Ibidem.

29 Ibidem.

30 Na podstawie wielu opracowań oraz przeprowadzonych badań uznaje się, że w społeczeństwie polskim przez lata utrwalany był podział na sferę typowo kobieca i typowo męską. Dotyczy to wielu kwestii, rozpoczynając od cech charakteru (kobiece - wrażliwość, empatia, niezdecydowanie, męskie natomiast - stanowczość, odwaga, zdecydowanie), poprzez wykonywane zawody (kobiece - nauczycielki, pielęgniarki, przedszkolanki oraz męskie - inżynierowie, budowlańcy, prezesi), kończąc na tradycyjnym ujmowaniu pozycji kobiet i mężczyzn w społeczeństwie (kobieta - matka, żona, opiekunka domowego ogniska, mężczyzna - głowa rodziny, zapewniający byt materialny). Problematyka ta od zawsze była obszarem badań wielu specjalistów. Zob. m.in. Magdalena Środa, Kobiety i władza, (Warszawa: Wydawnictwo W.A.B., 2012); Anna Titkow, Tożsamość kobiet polskich. Ciagłość, zmiana, konteksty, (Warszawa: Wydawnictwo IFiS PAN, 2007); Katarzyna Piątek, Anna Barabasz, Kobiet polskich dzisiejsze rozterki... Czyli o kobiecej roli $w$ utrwalaniu tradycyjnych relacji $w$ rodzinie, (Bielsko-Biała: Wydawnictwo Akademii Techniczno-Humanistycznej, 2007); Sławomira Walczewska, Damy, rycerze, feministki, (Kraków: Wydawnictwo eFKa, 1999).

31 „Cieszcie się swobodą. Wokół samotności (3)”, Kobieta i Życie, nr 45, 1988, 10.
} 
Swoją wypowiedź kończyła słowami skierowanymi do niezamężnych: „I w naszym, i w waszym życiu są blaski i cienie. Cieszcie się swobodą, otoczcie się przyjaciółmi i życie będzie wesołe. To nie te czasy, kiedy kobieta była uzależniona materialnie od mężczyzny!”32. Z kolei w głosie innej czytelniczki - „Wieloletniej mężatki ze Szczecina" dało się wręcz wyczuć pewną nutę zazdrości skierowaną pod adresem samotnych kobiet. Pisała:

Jak wiadomo, nie ma nic „za darmo”. Ja nie zaznałam w życiu samotności. Ale cenę za to płacę każdego dnia: cenę wyrzeczeń, ciężkiej pracy, zależności od drogiego mężczyzny. Do tego lęk o jego zdrowie i życie, i lęk przed starościa, jego i moja. A moja samotna, niby pokrzywdzona przyjaciółka kwitnie: myśli tylko o sobie, cały zarobek zużywa na własne przyjemności, domowe prace ogranicza do minimum, wyjeżdża często $z$ domu, bo może sobie na to pozwolić. A ja dmucham nieustannie $\mathrm{w}$ domowe ognisko i już na nic innego nie mam siły. Zaapelujcie, proszę, aby samotne panie nie zazdrościly mężatkom, tylko poszukały plusów swojej sytuacji. Nie zawsze mężczyzna zapewnia szczęście i spokój, jakże często ten spokój rujnuje i sam wymaga opieki i poświęcenia. Chyba się Panie ze mną zgodzą?33

\section{Podsumowanie}

Po analizie materiałów publikowanych na łamach „Kobiety i Życia" zauważyć można istotne zmiany, jakie zachodziły w kwestii prezentowania wizerunku oraz pozycji kobiet niezamężnych u schyłku PRL. W porównaniu $z$ wcześniejszym okresem coraz więcej tekstów ukazywało samotność jako świadomy wybór Polek, które decydowały się na samodzielność nie $z$ przymusu czy konieczności. Można wymienić różne motywacje kobiet wybierających samotna drogę życiową. Najczęśsiej uwarunkowane były przez okolicznościami życiowymi, jak niepowodzenia we wcześniejszych związkach, rozwody. Samotność w wyniku takich wydarzeń początkowo nie należała do najłatwiejszych, aczkolwiek $z$ czasem kobiety zaczęły dostrzegać pozytywne strony funkcjonowania w pojedynkę, m.in. swobodne decydowanie o swoim wolnym czasie oraz nieskrępowaną możliwość realizowania aspiracji zawodowych. Wśród pozostałych przyczyn samotności wymieniono m.in. dobrowolny wybór ko-

32 Ibidem.

33 „Nie ma czego zazdrościć. Wokół samotności (2)”, Kobieta i Życie, nr 33, 1988, 10. 
biety wynikający $\mathrm{z}$ braku potrzeby realizowania się $\mathrm{w}$ roli partnerki lub żony.

W periodyku przedstawiano również stereotypowe postrzeganie "starych panien", jednak zazwyczaj stanowiło to punkt wyjścia do głębszych rozważań dotyczących zachodzących ówcześnie przemian społecznych. Ponadto utrwalony wzorzec niezamężnych Polek starano się konsekwentnie potępiać, często stosując w tym celu ironię oraz sarkazm.

Omawiana problematyka często występowała w „Kobiecie i Życiu". Na łamach periodyku zamieszczano cyklicznie materiaky prasowe, w których poruszano zagadnienia dotyczące niezamężnych kobiet - wywiady, reportaże, wspomnienia. Wiele uwagi poświęcano również wypowiedziom nadsyłanym przez czytelniczki, które dzieliły się swoimi uwagami oraz odczuciami związanymi $\mathrm{z}$ życiem w pojedynkę. W dużej mierze wynikało to $\mathrm{z}$ profilu pisma, grona odbiorców, do jakich było kierowane, oraz faktu, że to właśnie „Kobieta i Życie” najbardziej skupiała się na szeroko rozumianej problematyce kobiecej, ich emocjach oraz aktualnej pozycji i statusie społecznym. Ponadto w latach 80 . XX w. wokół redakcji utworzył się swoisty ruch feministyczny, co znacząco wpłynęło na dobór publikowanych materiałów.

Z kolei „Przyjaciółka” od zawsze pozostawała pismem, na którego łamach przeważająca część tekstów traktowała o gospodarstwie domowym oraz tradycyjnym ujęciu roli kobiety - jako żony i matki. Pomimo że u schyłku lat 80 . XX w. zaczęły pojawiać się teksty przełamujace ten utrwalony model, np. dotyczące rozwodów czy samotnego rodzicielstwa, to miały one wyłącznie charakter poradnikowy. Redakcja czasopisma starała się pomóc czytelniczkom, podpowiadając, jak po rozwodzie zapewnić byt materialny sobie i dzieciom czy jak zadbać o komfort psychiczny potomstwa. Kobietę przedstawiano jako zagubiona i bezradna, która została zmuszona do samotności przez okoliczności życiowe. Taką, której należy udzielić porad w kwestii tego, jak ma się odnaleźć w nowej sytuacji, przede wszystkim finansowej. Nie poświęcano natomiast uwagi temu, jak czuje się samotna kobieta oraz w jaki sposób funkcjonuje w społeczeństwie. Przypuszczać można, że różnice w liczbie oraz charakterze publikacji dotyczących niezamężnych kobiet w „Kobiecie i Życiu” oraz „Przyjaciółce” wynikały także ze środowiska, w jakim czasopisma te cieszyły się największa popularnością. 
„Kobieta i Życie” od zawsze uchodziła za periodyk kierowany do kobiet mieszkajacych w miastach, natomiast „Przyjaciółka” miała największy odbiór wśród mieszkanek wsi. Niewątpliwie rzutowało to na liczbę oraz sposób ujmowania zagadnień dotyczacych kobiet żyjących w pojedynkę.

Natomiast „Zwierciadło” ze względu na powiązanie $z$ Liga Kobiet poruszało głównie zagadnienia natury politycznej ${ }^{34}$, nie skupiając sie zbyt mocno na omawianej problematyce. Jeśli zdarzały się materiały dotyczące niezamężnych kobiet, to utrwalały jedynie stereotypowe pojmowanie oraz tradycyjne postrzeganie roli kobiety i mężczyzny w społeczeństwie.

Teksty zamieszczane na łamach „Kobiety i Życia” stanowiły odzwierciedlenie tendencji ówcześnie panujących w społeczeństwie polskim. W drugiej połowie lat 80. XX w. poza wyczuwalnymi nadchodzącymi zmianami polityczno-ustrojowymi, dało się także zauważyć zbliżające się wielkimi krokami przemiany społeczne, m.in. w postrzeganiu niezamężnych kobiet. Ponadto warto zwrócić uwagę, że wzajemne relacje prasa-rzeczywistość przebiegały niejako dwutorowo. Po pierwsze, jak już wspomniano, były odbiciem panującej atmosfery. Po drugie natomiast, przez propagowanie określonych wzorców utrwalały je w społeczeństwie. Na obecność stereotypów w świadomości społecznej niewatpliwy wpływ wywieraja media masowe, w tym także prasa, która często w niezamierzony sposób kieruje odbiorcami, co bezpośrednio wiąze się $z$ kreowaniem wizji świata. Odbija się to $z$ kolei na kształtowaniu postaw, wzorów zachowań, wzmacnianiu określonych wartości czy stylów życia. Podobnie było także w wypadku redakcji „Kobiety i Życia”, która, upowszechniając wzorzec Polki żyjącej w pojedynkę, aczkolwiek nieczującej się samotną, starała się go utrwalić w społeczeństwie schyłku PRL.

\footnotetext{
34 Problematykę zagadnień politycznych poruszanych na łamach „Zwierciadła” oraz powiązań redakcji czasopisma z Ligą Kobiet szczegółowo zbadała Małgorzata Dajnowicz. Zob. m.in.: Małgorzata Dajnowicz, "Zwierciadło" - platforma polityczna Ligi Kobiet w okresie PRL (1957-1961, 1982-1989)”, Rocznik Historii Prasy Polskiej, t. XX, 2017, 67-90; eadem, „Kobiety - polityka - wybory w świetle "Zwierciadła. Pisma Ligi Kobiet Polskich" (1982-1990)”, w: Grzegorz Radomski, Michał Strzelecki, Katarzyna Sopolińska (red.), Rzeczpospolita $w$ koncepcjach polskich partii $i$ środowisk politycznych XX $i$ XXI wieku, (Toruń: Wydawnictwo Naukowe Uniwersytetu Mikołaja Kopernika, 2018), 107-125; eadem, „Posłanki Ligi Kobiet Polskich i wybory parlamentarne 1989 roku (prezentacja w świetle "Zwierciadła")", w: Małgorzata Dajnowicz, Adam Miodowski (red.), Polityka i politycy w prasie XX $i$ XXI wieku. Polityka w prasie kobiecej, (Białystok: Wydawnictwo Uniwersytetu w Białymstoku, 2019), 205-215.
} 


\section{Bibliografia}

\section{Źródła}

AAN, PZPR KC Wydział Prasy i Wydawnictw, sygn. 237 / XIX - 208, Uwagi o prasie kobiecej. „Kobieta i Życie”, „Przyjaciółka”, „Zwierciadło", styczeń - maj 1958 r.

\section{Źródla prasowe}

Bielicka, Alicja. „Trudny układ”, Kobieta i Życie, nr 32, 1988, 17.

„Cieszcie się swobodą. Wokół samotności (3)”, Kobieta i Życie, nr 45, $1988,10$.

„Inny gatunek kobiety?”, Kobieta i Życie, nr 9, 1984, 2.

"Iść czy nie iść. Wokół samotności”, Kobieta i Życie, nr 33, 1988, 11. „Jestem rozczarowana mężczyznami. Wokół samotności (3)”, Kobieta i Życie, nr 45, 1988, 10.

„Jestem sama, ale nie samotna. Wokół samotności (2)”, Kobieta i Życie, nr 33, 1988, 11.

„Nie czuję się samotna. Wokół samotności”, Kobieta i Życie, nr 18, 1988, 11.

„Nie ma czego zazdrościć. Wokół samotności (2)”, Kobieta i Życie, nr 33, 1988, 10.

„Nie rozpamiętywać minusów! Wokół samotności (3)”, Kobieta i Życie, nr 45, 1988, 10.

„Piętno. Wokół samotności”, Kobieta i Życie, nr 18, 1988, 10.

Ratyńska, Janina. „Rozwody i dzieci”, Przyjaciółka, nr 21, 1987, 3. „Samotne, samodzielne czy wyzwolone?”, Zwierciadło, nr 50, 1985, 4. „Sens społeczny starej panny”, Kobieta i Życie, nr 34, 1984, 15.

Stachowicz, Katarzyna. „A kobieta wiernie czeka...”, Zwierciadło, nr 1, 1983, 3.

„Z różnych szpalt. Kiedy wyjść za mąż?”, Przyjaciótka, nr 10, 1987, 11.

\section{Opracowania}

Czarnecka, Julita. „Polski singiel: obraz w mediach a autowizerunek", w: Ewa Malinowska (red.), Stereotypy a rzeczywistość na przykładzie wybranych kategorii społecznych, (Łódź: Oficyna Wydawnicza Tercja, 2008), 110-137.

Ćwik, Urszula. „Podstawowe założenia Społeczno-Obywatelskiej Ligi Kobiet w świetle "Mody i Życia Praktycznego" (1946-1951)", w: Małgorzata Dajnowicz, Adam Miodowski (red.), Polityka i politycy 
w prasie XX i XXI wieku. Prasa organizacji politycznych, (Białystok: Wydawnictwo Humanica, 2017), 49-58.

Ćwik, Urszula. „Wybory parlamentarne i wybory do rad narodowych w Polskiej Rzeczypospolitej Ludowej na łamach "Kobiety i Życia" (do 1989 roku)", w: Małgorzata Dajnowicz, Adam Miodowski, Polityka i politycy $w$ prasie XX $i$ XXI wieku, (Białystok: Wydawnictwo Humanica, 2016), 328-337.

Dajnowicz, Małgorzata. „Kobiety - polityka - wybory w świetle "Zwierciadła. Pisma Ligi Kobiet Polskich" (1982-1990)", w: Grzegorz Radomski, Michał Strzelecki, Katarzyna Sopolińska (red.), Rzeczpospolita $w$ koncepcjach polskich partii $i$ środowisk politycznych XX i XXI wieku, (Torun: Wydawnictwo Naukowe Uniwersytetu Mikołaja Kopernika, 2018), 107-125.

Dajnowicz, Małgorzata. „Kobiety w polityce w wypowiedziach prasowych Krystyny Kaszuby na łamach "Kobiety i Życia" (19851990)", w: Ewa Maj, Ewelina Podgajna, Anna Szwed-Walczak, Łukasz Jędrzejski (red.), Komunikowanie polityczne, (Lublin: Wydawnictwo UMCS, 2017), 199-210.

Dajnowicz, Małgorzata. „Posłanki Ligi Kobiet Polskich i wybory parlamentarne 1989 roku (prezentacja w świetle "Zwierciadła»)", w: Małgorzata Dajnowicz, Adam Miodowski (red.), Polityka i politycy $w$ prasie XX i XXI wieku. Polityka $w$ prasie kobiecej, (Białystok: Wydawnictwo Uniwersytetu w Białymstoku, 2019), 205-215.

Dajnowicz, Małgorzata. „Wzorce aktywności publicznej kobiet w początkach transformacji ustrojowej w Polsce w świetle "Kobiety i Życia" i "Urody" (1989-1995)", w: Teresa Kulak, Małgorzata Dajnowicz (red.), Drogi kobiet do polityki (na przestrzeni XVIII-XXI wieku), (Wrocław: Wydawnictwo Chromcom, 2016), 417-443.

Dajnowicz, Małgorzata. „Zwierciadło” - platforma polityczna Ligi Kobiet w okresie PRL (1957-1961, 1982-1989)", Rocznik Historii Prasy Polskiej, t. XX, 2017, 67-90.

Kopaliński, Władysław. Słownik wyrazów obcych i zwrotów obcojęzycznych $z$ almanachem, (Warszawa: Oficyna Wydawnicza Rytm, 2014).

Mandal, Eugenia. Podmiotowe i interpersonalne konsekwencje stereotypów zwiąanych $z$ plcia, (Katowice: Wydawnictwo Uniwersytetu Ślasskiego, 2000).

Piątek, Katarzyna, Barabasz, Anna. Kobiet polskich dzisiejsze rozterki... Czyli o kobiecej roli $w$ utrwalaniu tradycyjnych relacji 
$w$ rodzinie, (Bielsko-Biała: Wydawnictwo Akademii Techniczno -Humanistycznej, 2007).

Slany, Krystyna. Alternatywne formy życia małżeńsko-rodzinnego $w$ ponowoczesnym świecie, (Kraków: Zakład Wydawniczy Nomos, 2002).

Środa, Magdalena. Kobiety i władza, (Warszawa: Wydawnictwo W.A.B., 2012).

Titkow, Anna. Tożsamość kobiet polskich. Ciagłość, zmiana, konteksty, (Warszawa: Wydawnictwo IFiS PAN, 2007).

Walczewska, Sławomira. Damy, rycerze, feministki, (Kraków: Wydawnictwo eFKa, 1999).

\section{Publikacje internetowe}

Kazimiera Szczuka, „Sama nie samotna”, Serwis Informacyjny Tygodnika Polityka, [online] [dostęp: 30.01.2017]. Dostępny w World Wide Web: <http://www.polityka.pl/tygodnikpolityka/ kultura/254106,1,sama-nie-samotna.read>.

Słownik języka polskiego PWN, [online] [dostęp: 4.05.2017]. Dostępny w World Wide Web: <http://sjp.pwn.pl/sjp/;2576254>. 